\title{
Analysis of the Investment Economic Benefit on Renqiu Buried Hill Reservoir Lift Methods Conversion
}

\author{
Yan Gao \\ The First Oil Production Plant \\ Petrochina Huabei Oilfield Company, Renqiu, China \\ cyl_gy@petrochina.com.cn \\ Yongxiang Yang \\ Oil Production Engineering Research Institute \\ Petrochina Huabei Oilfield Company, Renqiu, China \\ cyy_yangyx@petrochina.com.cn

\section{Yongning Yang} \\ Hebei Huabei Petroleum Rongsheng Machinery \\ Manufacture Ltd., Renqiu, China \\ yyn92@aliyun.com
}

\author{
Xuexia Wei \\ Administrative Affairs Center \\ Petrochina Huabei Oilfield Company, Renqiu, China \\ swb_wxx@petrochina.com.cn
}

\section{Anqi Yang}

The First Oil Production Plant

Petrochina Huabei Oilfield Company, Renqiu, China cy1_yaq@petrochina.com.cn

\author{
Shian Lu \\ The First Oil Production Plant \\ Petrochina Huabei Oilfield Company, Renqiu, China \\ cy11san@petrochina.com.cn \\ Lei Chen \\ Exploitation and Development Research Institute \\ Petrochina Huabei Oilfield Company, Renqiu, China \\ yjy_chenlei@petrochina.com.cn
}

Aiqin Liu

Oil Production Engineering Research Institute Petrochina Huabei Oilfield Company, Renqiu, China cyy liuaiq@petrochina.com.cn

\section{Baohui Zhang}

Oil Production Engineering Research Institute Petrochina Huabei Oilfield Company, Renqiu, China cyy_zangbh@petrochina.com.cn

Jing Wang

Exploitation and Development Research Institute Petrochina Huabei Oilfield Company, Renqiu, China yjy_wjing1@petrochina.com.cn

\begin{abstract}
Renqiu buried hill reservoir of electric submersible pump well in order to reduce the sewage invalid recycling and saving energy, using the electric submersible pump(ESP) well convert into pumping unit well to produce. The scheme design lifting process adjustment and optimization of 13 wells. Through the analysis of economic benefit, 13 ESP wells convert into the pumping unit wells will obtain the production economic benefit of 5.5809 million Yuan. The investment recovery period is 24 months. The field application results are obvious, reaching the purpose of energy saving.
\end{abstract}

Keywords-Renqiu buried hill reservoir; electric submersible pump; pumping unit well; lift methods; economic benefit analysis.

\section{INTRODUCTION}

Renqiu buried hill reservoir began to implement the control of injection and depressurizing production from $1991[1,2,3]$. Due to reservoir formation pressure drop, the well PFL reducing, lifting height and discharge requirements. We began to apply a large number of ESP production, ESP plays an important role in the buried hill reservoir exploitation. Control of water injection and depressurizing production ended in 1999. With the gradual realization of all the sewage reinjection, the reservoir pressure gradually recover, the well PFL rising, pumping unit has been to meet some wells production needs. This paper studies the production status of ESP well, ESP wells were directly converted to the pumping unit wells or treated after converting the pumping unit wells, which reduce the amount of sewage invalid cycle, to achieve energy saving purpose.

\section{THE PROCESS CHARACTERISTICS AND LIMITATIONS OF ESP}

The characteristics of the ESP is a "large displacement, high lift, rodless lifting" [4, 5]. In order to meet the Renqiu buried hill reservoir deep well pumping "large displacement, high lift" production demand, ESP technology is mainly applied in the following three kinds of oil well:

i) The high water cut wells at Renqiu buried hill reservoir need "large displacement, high lift" of ESP. Renqiu buried hill reservoir in middle and later periods of 
the development, water cut is high, the PFL is deep. Due to depressurizing production, tubing pump cannot meet the need of production. Using large displacement, high lift ESP, there are 28 Wells, accounting for more than $85 \%$ of the well.

ii) Rod tube eccentric wear seriously deviated wells. Use the small displacement ESP for rodless oil production. There are 4 small displacement ESP wells now.

iii) Surface environment is poor, near the city production of oil Wells. ESP has the characteristics of small occupation area, low noise, which can solve the production problem of special production environment requirements.

Under certain conditions, mechanical oil production equipment has the limitations of its economy and operation, etc. Select the mode of mechanical production wells, the main standard to measure is the minimum investment for maximum economic benefit. Along with the progress of reservoir development, affected by the reservoir energy, production situation and other factors changing, the ESP lifting method, system of work adaptability and economic benefits have also changed.

Buried hill reservoir formation pressure has been restored and part of the ESP production need to adjust the lifting way optimization. ESP production statistics from 1994 to 2012, 19 years production situation can be seen that as the Renqiu buried hill reservoir from 1999 began to recover water injection, injection of water increases, formation energy gradually restored, working fluid level began to rise from 2007, the average single well working fluid level rise from $1007 \mathrm{~m}$ to $693 \mathrm{~m}$, water cut from $81.9 \%$ to $95.8 \%$, the single well oil production from 30.4 $\mathrm{t} / \mathrm{d}$ reduce to $7.4 \mathrm{t} / \mathrm{d}$.

ESP oil production is high energy consumption. According to 32 ESP wells production power consumption statistics, the average single well power $53 \times 10^{4} \mathrm{~kW} \cdot \mathrm{h}$, average tons of fluid power $7.9 \mathrm{~kW} \cdot \mathrm{h}$, tons of liquid hundred meters power $1.021 \mathrm{~kW} \cdot \mathrm{h}$. And 175 pumping unit wells production power consumption statistics, the average single well power consumed $7.9 \times 10^{4} \mathrm{~kW} \cdot \mathrm{h}$, average tons of fluid power $2.8 \mathrm{~kW} \cdot \mathrm{h}$, tons of liquid hundred meters power $0.53 \mathrm{~kW} \cdot \mathrm{h}$. By comparison, ESP in single well power consumption is 6.7 times that of the pumping unit well, tons of liquid hundred meters consumes nearly 2 times (Table 1).

TABLE I. MECHANICAL PRODUCTION WELLS IN RENQIU BURIED Hill Reservoir Single Well AVERAGE POWER CONSUMPTION STATISTICS

\begin{tabular}{|c|c|c|}
\hline Lift methods & ESP & Pumping unit \\
\hline Statistics the number of wells & 32 & 175 \\
\hline The average pump deep $(\mathrm{m})$ & 1191.7 & 1116.4 \\
\hline Fluid $(\mathrm{t} / \mathrm{d})$ & 186.0 & 77.3 \\
\hline Oil $(\mathrm{t} / \mathrm{d})$ & 8.19 & 3.65 \\
\hline Theory of displacement $\left(\mathrm{m}^{3} / \mathrm{d}\right)$ & 147.41 & 91.87 \\
\hline Pump efficiency $(\%)$ & 127.80 & 84.14 \\
\hline Working fluid level $(\mathrm{m})$ & 775.6 & 523.4 \\
\hline Power consumed $\left(\times 10^{4} \mathrm{~kW} \cdot \mathrm{h}\right)$ & 53.01 & 7.90 \\
\hline $\begin{array}{c}\text { Tons of fluid power } \\
\text { consumption }(\mathrm{kW} \cdot \mathrm{h})\end{array}$ & 7.917 & 2.800 \\
\hline $\begin{array}{c}\text { Tons of liquid hundred } \mathrm{meters} \\
\text { power consumption }(\mathrm{kW} \cdot \mathrm{h})\end{array}$ & 1.021 & 0.530 \\
\hline
\end{tabular}

\section{FEASIBILITY ANALYSIS OF ESP CONVERTING INTO PUMPING UNIT}

In the existing conventional "three pumping (pumping unit, pump, sucker rod)" conditions, the ESP well whether can convert into pumping unit well to meet production are mainly three factors: i) After ESP well convert into pumping unit well, the production output whether can remain basically unchanged; ii) Pumping unit production of lifting process (including the pumping unit, rod, pump, etc.) whether can meet the needs of the oil well production; iii) The surface environment whether to allow fix pumping unit production.

Therefore, in order to "ensure the well oil production basically remain unchanged, the existing three pumping equipment maximum allowable conditions, surface conditions permit", searching for Renqiu buried hills of ESP wells, 13 wells can convert into pumping unit production. Therefore, in order to "ensure the well oil production basically remain unchanged, the existing three pumping equipment maximum allowable conditions, surface conditions permit", searching for Renqiu buried hills of ESP wells, 13 wells can convert into pumping unit to produce. Among them, RX472, RG6, C3P2, RP4, R217, RP7, 6 wells can directly convert into pumping unit to produce, through optimizing design, keep oil production unchanged; R316 RJ7, R340, R380, RX1-3, RX331, R323, 7 Wells working fluid level is high, producing fluid volume is high, the existing tubing pump capacity is small, cannot satisfy the need, through the analysis of the reservoir potential, to implement water plugging measures, reduce the amount of liquid producing after pumping unit production $[6,7,8,9,10]$.

TABLE II. OIL Well Sucker Rod Pump Lifting Process PARAMETERS

\begin{tabular}{|c|c|c|c|c|c|}
\hline \multicolumn{2}{|c|}{$\begin{array}{c}\text { The well } \\
\text { proration } \\
\text { requirements }\end{array}$} & \multicolumn{4}{|c|}{ Three pumping equipment and operating } \\
parameters
\end{tabular}

\section{The Adjustment Optimization Scheme of LIFTING PROCESS FOR ESP WELL}

In view of the actual problems of high energy consumption of ESP wells, we adjusted the lifting process of 13 ESP wells to optimization combined with the factors such as "the well behavior after converting to pumping unit well, the risk of treating, the surface condition", based on "the oil well status, formation potential and geological research".

According to the production situation and the formation of wells, we formulate different schemes. After 
converting 13 ESP wells to pumping unit wells, the fluid production per day will reduce $1049 \mathrm{t}$. Less of water production per day is $1049 \mathrm{t}$, and that is $38.29 \times 10^{4} \mathrm{~m}^{3}$ per year.

Scheme A: Six ESP wells convert to pumping unit wells directly. After converting, the fluid production per day will reduce $41 \mathrm{t}$. The oil production per day will increase $0.1 \mathrm{t}$. Less of water production per day is $41 \mathrm{t}$.

Scheme B: Seven ESP wells turn to pumping unit wells after treating. Through reservoir potential research and treating risk evaluation, we turn seven ESP wells with high water production to pumping unit wells after WSO. Under the condition of the ideal treating prediction, the oil production per day is unchanged after WSO. After treating the fluid production per day and the producing fluid level (PFL) can meet the production conditions (the pump diameter is $70 \mathrm{~mm}$. Working system of the pumping unit is $4.8 \mathrm{~m}, 5$ times $/ \mathrm{min}$. The water production is $100 \mathrm{~m}^{3} / \mathrm{d}$ ). After treating and converting to pumping unit wells, the daily fluid production of the seven ESP wells is expected to reduce $1008 \mathrm{t}, 1008 \mathrm{t}$ of the water reduction, 144t of the average single well water production, and decrease water cut $3.8 \%$.

After calculating the theoretical load of the 13 wells, we could choose 3 pumping units of 10-type, 1 pumping unit of 12-type, 9 pumping units of 14-type. Considering the treating and deepening in the future, we determine to select 13 pumping units of 14-type. Though there are 3 old pumping units, which can't meet the need, we need 13 new pumping units. The original transformer, Christmas tree etc. all need to be replaced.

\section{INVESTMENT AND ECONOMIC BENEFIT ANALYSIS}

Investment of implementation of converting ESP to pumping unit mainly has two aspects. First is surface equipment investment, including the new beam pumping unit, replace the transformer, Christmas tree and so on. The second is the cost of pump operating, treating and the new rod, new pump.

The benefit mainly has two aspects. First is electricity charge that is saved. The second, as reducing invalid circulation of water, the disposal cost of produced fluid is saved after WSO, including produced fluid gathering process and sewage recycle, etc.

\section{A. Front End Investment}

Analyzing all the production preparations for converting to pumping unit, front end investment projected is 11.474 million Yuan.

Among them, the investment in pumping unit, pump and sucker rod is 7.674 million Yuan (Table 3).

The treating cost before converting to pumping unit is expected to 3.8 million Yuan (Table 4).

\section{B. Economic Benefit Analysis}

The benefit of ESP converting to pumping unit is mainly manifested on saving electricity charge because of power consumption reduction significantly and cutting down the cost of sewage recycle when the wells reduce the water output. The recycling of old ESP equipment and saving operation cost of the 13 converting wells are not included.
TABLE III. INVESTMENT IN PUMPING UNIT, PUMP AND SUCKER ROD

\begin{tabular}{|c|c|c|c|c|c|c|}
\hline No. & Equipment & $\begin{array}{c}\text { Format and } \\
\text { Type }\end{array}$ & Unit & $\begin{array}{c}\text { Qua- } \\
\text { ntity }\end{array}$ & $\begin{array}{c}\text { Unit } \\
\text { price } \\
(\times \mathbf{1 0} \\
\text { Yuan) }\end{array}$ & $\begin{array}{c}\text { Total } \\
\text { price } \\
(\times \mathbf{1 0} \\
\text { Yuan) }\end{array}$ \\
\hline 1 & $\begin{array}{c}\text { pumping } \\
\text { unit }\end{array}$ & $\begin{array}{c}\text { CYJW14-5- } \\
73 \mathrm{~F}\end{array}$ & case & 13 & 38.0 & 494.0 \\
\hline 2 & sucker rod & $\Phi 19 \mathrm{~mm}$ & $\mathrm{~m}$ & 3438 & 0.0039 & 13.4 \\
\hline 3 & sucker rod & $\Phi 22 \mathrm{~mm}$ & $\mathrm{~m}$ & 5532 & 0.0043 & 23.8 \\
\hline 4 & sucker rod & $\Phi 25 \mathrm{~mm}$ & $\mathrm{~m}$ & 5980 & 0.0050 & 29.9 \\
\hline 5 & pump & $\Phi 83 \mathrm{~mm} \times 7.7 \mathrm{~m}$ & case & 1 & 1.2 & 1.2 \\
\hline 6 & pump & $\Phi 70 \mathrm{~mm} \times 7.7 \mathrm{~m}$ & case & 10 & 1.0 & 10.0 \\
\hline 7 & pump & $\Phi 56 \mathrm{~mm} \times 7.7 \mathrm{~m}$ & case & 1 & 0.8 & 0.8 \\
\hline 8 & pump & $\Phi 44 \mathrm{~mm} \times 7.7 \mathrm{~m}$ & case & 1 & 0.6 & 0.6 \\
\hline 9 & well head & KYS25/65 & case & 13 & 3.5 & 45.5 \\
\hline 10 & transformer & $50 \mathrm{kVA}$ & case & 13 & 2.5 & 32.5 \\
\hline 11 & $\begin{array}{c}\text { pumping } \\
\text { unit fixing }\end{array}$ & & case & 13 & 3.0 & 39.0 \\
\hline 12 & $\begin{array}{c}\text { putting on } \\
\text { pump }\end{array}$ & & well & 13 & 5.9 & 76.7 \\
\hline & Total & & & & & 767.4 \\
\hline
\end{tabular}

TABLE IV. TREATING COST BUdGET FOR ESP WELLS

\begin{tabular}{|c|c|c|c|}
\hline No. & $\begin{array}{l}\text { Well } \\
\text { ID }\end{array}$ & Treating & $\begin{array}{c}\operatorname{Cost}\left(\times 10^{4}\right. \\
\text { Yuan) }\end{array}$ \\
\hline 1 & R316 & $\begin{array}{l}\text { WSO, cement squeezing pointfree to } \\
3050 \mathrm{~m} \text {; according to the water } \\
\text { absorbing capacity after WSO, } \\
\text { determine to reshoot and acid } \\
\text { treatment }\end{array}$ & 75 \\
\hline 2 & RJ7 & $\begin{array}{l}\text { WSO; according to the water } \\
\text { absorbing capacity after WSO, } \\
\text { determine to acid treat }\end{array}$ & 50 \\
\hline 3 & R340 & $\begin{array}{l}\text { WSO, cement squeezing pointfree to } \\
3114 \mathrm{~m} \text {; according to the water } \\
\text { absorbing capacity after WSO, } \\
\text { determine the next treating }\end{array}$ & 50 \\
\hline 4 & R380 & $\begin{array}{l}\text { according to the effect of the well } \\
\text { R340 treating scheme, if it is feasible, } \\
\text { cement squeezing pointfree to } 3155 \mathrm{~m} \text {; } \\
\text { if it is unfeasible, WSO }\end{array}$ & 50 \\
\hline 5 & RX1-3 & Organic WSO & 50 \\
\hline 6 & RX331 & Organic WSO & 50 \\
\hline \multirow[t]{2}{*}{7} & R323 & Organic WSO & 55 \\
\hline & Total & & 380 \\
\hline
\end{tabular}

13 wells plans to turn ESP production to pumping unit. Before converting, the measured power consumption is $688.1 \times 10^{4} \mathrm{~kW} \cdot \mathrm{h}$. After converting, when the power consumption of the pumping unit well is $0.53 \mathrm{~kW} \cdot \mathrm{h} / \mathrm{t} /$ hundred meters, estimated power consumption per year is $188.2 \times 10^{4} \mathrm{~kW} \cdot \mathrm{h}$. Power saving rate predicted is $72 \%$. Power saving per year is expected to $499.93 \times 10^{4} \mathrm{~kW} \cdot \mathrm{h}$ (Table 5). When the electricity calculated at 0.81 Yuan $/ \mathrm{kW} \cdot \mathrm{h}$, we can save 4.0494 million Yuan per year.

After 13 ESP wells converting, there is expected to reduce fluid $1049 \mathrm{t} / \mathrm{d}$, water $1049 \mathrm{t} / \mathrm{d}$, water production $38.3 \times 10^{4} \mathrm{~m}^{3}$ per year. As the liquid disposal cost is 1.5 Yuan/t. The sewage recycle cost $2.5 \mathrm{Yuan} / \mathrm{t}$, it is expected 
TABLE V. Forecast FOR THE SINGLE WELl POWER CONSUMPTION CONTRAST

\begin{tabular}{|c|c|c|c|c|c|}
\hline No. & Well ID & $\begin{array}{c}\text { The } \\
\text { measur } \\
\text { ed } \\
\text { power } \\
\text { consu } \\
\text { mption } \\
\text { of ESP } \\
\text { well } \\
(\mathrm{kW} \cdot \mathrm{h})\end{array}$ & $\begin{array}{c}\text { Power } \\
\text { consump } \\
\text { tion per } \\
\text { year } \\
\left(\times 10^{4}\right. \\
\mathbf{k W} \cdot \mathbf{h})\end{array}$ & $\begin{array}{c}\text { Predictiv } \\
\text { e power } \\
\text { consumpt } \\
\text { ion per } \\
\text { year of } \\
\text { pumping } \\
\text { unit } \\
\left(\times 10^{4}\right. \\
\mathrm{kW} \cdot \mathrm{h}) \\
\end{array}$ & $\begin{array}{c}\text { Power } \\
\text { saving } \\
\left(\times 10^{4}\right. \\
\mathbf{k W} \cdot \mathbf{h})\end{array}$ \\
\hline 1 & RX472 & 31842 & 38.21 & 11.1 & 27.07 \\
\hline 2 & RP4 & 49369 & 59.24 & 2.5 & 56.75 \\
\hline 3 & RP7 & 42714 & 51.26 & 6.5 & 44.76 \\
\hline 4 & RG6 & 46399 & 55.68 & 17.2 & 38.46 \\
\hline 5 & R217 & 28266 & 33.92 & 10.2 & 23.71 \\
\hline 6 & $\mathrm{C} 3 \mathrm{P} 2$ & 43399 & 52.08 & 13.8 & 38.26 \\
\hline 7 & RJ7 & 41817 & 50.18 & 17.7 & 32.45 \\
\hline 8 & R323 & 57833 & 69.40 & 19.3 & 50.13 \\
\hline 9 & R340 & 50035 & 60.04 & 17.3 & 42.70 \\
\hline 10 & R380 & 46278 & 55.53 & 19.3 & 36.27 \\
\hline 11 & R316 & 34566 & 41.48 & 17.7 & 23.75 \\
\hline 12 & RX1-3 & 42714 & 51.26 & 17.7 & 33.53 \\
\hline 13 & RX331 & 58186 & 69.82 & 17.7 & 52.10 \\
\hline & Total & & 688.10 & 188.2 & 499.93 \\
\hline
\end{tabular}

to cut down produced fluid disposal cost about 1.5315 million Yuan per year. Among them, the annual produced fluid disposal saves 0.5743 million Yuan. The water reinjection cost 0.9572 million Yuan per year.

\section{The Payback Period of Investment}

Economic benefits of 13 ESP wells converting to pumping unit (million Yuan)

$=$ saved electricity charge + saved liquid disposal cost

$=4.0494+1.5315$

$=5.5809$

Investment in Disposable equipment and treating (million Yuan)

$=11.474$ million Yuan.

Payback period of investment is about 24 months.

\section{FIELD IMPLEMENTATION}

Until February 2014, six ESP wells have been converted to pumping unit wells directly. Before converting, the liquid production is $547 \mathrm{t} / \mathrm{d}$, oil $33 \mathrm{t} / \mathrm{d}$, water cut $93.9 \%$, PFL $784 \mathrm{~m}$. After converting, the oil production is stable. In October 2014, the liquid production is $433 \mathrm{t} / \mathrm{d}$, oil $28 \mathrm{t} / \mathrm{d}$, water cut $93.5 \%$, PFL 1451 $\mathrm{m}$.

Until March 2014, 5 ESP wells have been converted to pumping unit wells after WSO. Before converting, the liquid production is $1040 \mathrm{t} / \mathrm{d}$, oil $20 \mathrm{t} / \mathrm{d}$, water cut $98.1 \%$, PFL $574 \mathrm{~m}$. After converting, the oil production is stable. In October 2014 , the liquid production is $380 \mathrm{t} / \mathrm{d}$, oil $12 \mathrm{t} / \mathrm{d}$, water cut $96.8 \%$, PFL $613 \mathrm{~m}$.
The reduction of accumulated water production is $27.6 \times 10^{4} \mathrm{t}$ per year. When the water production is reduced, the oil production is also decreased.

In Field implementation, contrasting the electricity consumption of 11 wells after converting to pumping unit with that of ESP wells, the scheme reduce $402.2 \times 10^{4} \mathrm{~kW} \cdot \mathrm{h}$, saving electricity charge 3.2578 million Yuan and produced fluid disposal 1.1040 million Yuan. The effect of energy conservation and power consumption reducing is obvious.

\section{CONCLUSIONS}

In this paper, according to the technological characteristics and limitations of ESP oil production, Analysis the feasibility of ESP well convert into pumping unit well. Put forward optimization scheme of 13 wells and the analysis of economic benefits. 11 wells on-site implementation, achieve the desired energy saving effect, energy saving effect is obvious.

\section{REFERENCES}

[1] Xuechen Zhang, et al, "Depressurization recovery test of Wumishan oil reservoir," Exploitation and Development, vol. 25(3), pp. 80-82, 1998.

[2] Jianguo Yuan, et al. "Practice and knowledge of later period comprehensive adjustment of Wuminshan high water cut reservoir, Renqiu oilfield," Journal of Xi'an Petroleum Institute, vol. 11(4), pp. 25-28, 1996.

[3] Renda Liu, et al, "Basic measures and effect of stabilizing oil production from Wumishan-formation reservoir in Renqiu county by controlling water injection during late high water-cut stage," Oil \& Gas Recovery Technology, vol. 1(1), pp. 29-35, 1994.

[4] Baiping He, Xiaoping Wang, et al, Esp Production Technology Ttranslation Collections, Petroleum Industry Press: Beijing, 1993.

[5] Wenxing Wei, Chun Lan. Lifting method optimization during the high-water cut period in Tuha oilfield, Tuha Oil \& Gas, vol. 9(2): pp. 151-155, 2004.

[6] Shugui Fu, et al, "Preliminary investigation to efficiency of pumping system in Wumishan reservoirs of Renqiu oilfield," Oil Drilling \& Production Technology, vol. 20(4) pp. 94-97, 1998.

[7] Xuechen Zhang, "Practice and understanding for water plugging of Renqiu buried hill reservoir in high water cut period," Oil \& Gas Recovery Technology, vol. 4(2), pp. 36-41, 1997.

[8] Xinya Wu, et al, "Research and application of TC-938 blocking agent in limestone reservoir," Oil Drilling \& Production Technology, vol. 20(3) pp. 81-84, 1998.

[9] Yuguang Geng, et al, "Stimulation technologies and applying effects in Renqiu buried hill reservoir," Oil Drilling \& Production Technology, vol. 22(6) pp. 45-50, 2000.

[10] Zhaocai Pan, et al, "Water plugging and tapping potential integrated technology for fracture-vug carbonates oil wells at high water-cut stage," Oil Drilling \& Production Technology, vol. 35(5) pp. 92-96, 2013. 